\title{
Effectiveness of Positive Selection in Managing Seed-Borne Potato Viruses
}

\author{
Gidraf Onduru Okeyo ${ }^{1}$, Kalpana Sharma $^{2}$, Elly Atieno ${ }^{2}$, Rama Devi Narla ${ }^{1}$, Douglas Watuku Miano ${ }^{1}$ \\ \& Elmar Schulte-Geldermann ${ }^{2}$ \\ ${ }^{1}$ Department of Plant Science and Crop Protection, University of Nairobi, Nairobi, Kenya \\ ${ }^{2}$ CGIAR Research Program on Roots, Tubers and Bananas (RTB), International Potato Center, Regional Office \\ Sub-Saharan Africa, ILRI Campus, Nairobi, Kenya \\ Correspondence: Elmar Schulte-Geldermann, CGIAR Research Program on Roots, Tubers and Bananas (RTB), \\ International Potato Center, Regional Office Sub-Saharan Africa, ILRI Campus, Nairobi, Kenya. E-mail: \\ e.schulte-geldermann@cgiar.org
}

Received: November 12, 2017

Accepted: January 22, 2018

Online Published: February 15, 2018

doi:10.5539/jas.v10n3p71

URL: https://doi.org/10.5539/jas.v10n3p71

\begin{abstract}
Potato productivity in Kenya has remained below the potential due to the use of infected seed tubers especially by seed borne viruses. A study was carried out to asses the effectiveness of Positive Selection (PS) in managing seed borne potato viruses. Sprouted seed potato tubers of nine genotypes; three commercial varieties and six advanced International Potato Center (CIP) clones were screened in the field for two seasons, Field Generation Three (FG3) and Field Generation Four (FG4), respectively. In each season, experimental plots were divided into two sub-plots in which one sub-plot was planted with seed tubers sourced through Random Seed Selection (RSS) and the other with seed tuber sourced through Positive Selection (PS). Positive selection plots had low visual virus incidences, high number of tubers per hill and yield (t/ha) in both FG3 and FG4 growing seasons irrespective of the genotypes. ELISA test also revealed that Potato Virus $S$ (PVS) (78\%) was the most predominant virus followed by Potato Virus Y (PVY) (20\%), Potato Leaf Roll Virus (PLRV) (16\%) and Potato Virus M (PVM) (9\%) in RSS plots either with single or multiple infections. Positive Selection plots recorded low virus incidences of PVS (47\%), and PVY, PLRV and PVM were absent in the tubers tested with ELISA. This study concludes that Positive Selection is a good management strategy to manage the seed borne potato viruses, and if adopted, small holder farmers can reduce the yield losses arising from use of virus infected seed tubers.
\end{abstract}

Keywords: potato genotype, positive selection, random seed selection, seed-borne viruses

1. Introduction

Potato (Solanum tuberosum L.) is ranked the third after rice and wheat among the most consumed crops worldwide (Wang'ombe \& Dijk, 2013). The crop plays a major role in poverty alleviation through income generation and creation of employment to people working in potato industry for the small scale farmers of Kenya (Gildemacher et al., 2011). It is grown in the high-altitude areas of Kenya (1,500-3,000 msl), which includes the slopes of Mt. Kenya, such as Meru, Embu, Kirinyaga, parts of Laikipia and Aberdare range that covers parts of Nyeri, Muranga, Kiamba and Nyandarua. Potatoes are also grown in the highlands on Mau Escarpment (Mau, Narok and Molo), Tinderet, Nandi Escarpment and Cherangani hills. Some small acreage has also been reported in Kericho and Kisii areas as well as in Taita hills (Janssens et al., 2013).

Potato yields are generally low due to field infections by the seed borne pathogens especially viruses (Schulte-Geldermann et al., 2012). Use of virus infected seed potato tubers has resulted into high yield losses up to $68 \%$, which mostly go unrealized in production fields free from bacterial and fungal diseases because their field diagnosis is difficult and or poorly understood by most farmers (Kabira et al., 2006). Yield losses following virus infection is variety specific, and potato varieties react differently to the type of virus, its growth stage and infection type (Ali et al., 2013; Rahman et al., 2010). Six potato viruses namely Potato Leaf Roll Virus (PLRV), Potato Virus A (PVA), Potato Virus M (PVM), Potato Virus $S$ (PVS), Potato Virus X (PVX), and Potato Virus $Y$ (PVY) and four aphid vector species namely Macrosiphum euphorbiae, Aphis gossypii, Myzus persicae, and Aphis fabae are known to affect potato production in Kenya causing low yields (Were et al., 2013). Kenya produces an average of $7.7 \mathrm{t} / \mathrm{ha}$ of potatoes per season which is much less than the potential yield of 40-50 t/ha. 
However, this figure has varied considerably over the recent years ranging from 3 to $9.5 \mathrm{t} / \mathrm{ha}$ (Gildemacher et al., 2011).

Different virus management options like use of certified seed potato tubers (Thomas-Sharma et al., 2016), positive selection of seed tubers from healthy looking and vigorous mother plants (Gildemacher et al., 2011), use of aeroponics in seed production (Tshisola, 2014), cultural control methods such as use of mineral oils and border crops (Fereres, 2000) and resistant varieties have been proposed as a solution to this problem. However, adopting some of these management strategies has been a challenge to most of the small holder farmers. More than $95 \%$ of seed potato tubers planted by farmers in Kenya are sourced from informal sources, and are of poor health status (Schulte-Geldermann, 2013). This is due to high prices coupled with unavailability of certified seed tubers to farmers (Kyamanywa et al., 2011; Janssens et al., 2013). Most of the cultural control strategies like mineral oils and barrier crops are only effective against non-persistence virus transmission through aphid vectors, and are ineffective against viruses that are transmitted via a mechanical means and other aphid vectors known to transmit viruses in persistence manner (Fereres, 2000).

Positive selection is an ancient technology that was used informal seed potato multiplication to select healthy looking mother plants from potato growing fields as a starting point in seed multiplication system (Gildemacher et al., 2011; Schulte-Geldermann, 2013). Asymptomatic mother plants are marked in the field before crop senescence to serve as seed source in the next generation. However, this technology is neither practiced by ware potato producers, nor promoted because it is regarded as obsolete informal seed production. Seed producers prefer to multiply seeds from tested, disease free, tissue culture material or from other nuclear stocks proven to be disease free (Gildemacher et al., 2011). In Kenya, positive selection was introduced by International Potato Center (CIP) in 2004 with the aim of training ware potato farmers on its importance. The know-how of positive selection, if adopted and put into practice can provide an option to small-holder famers in reducing seed borne pathogens mainly viruses at farm level (Gildemacher et al., 2011; Schulte-Geldermann et al., 2012). However, it is not commonly practiced by farmers due to lack of knowledge on its effectiveness, difficulties in diagnosis of different viruses in the field using visual symptoms and small-scale nature of their farming enterprises (Kabira et al., 2006; Gildemacher et al., 2011). The aim of this study was to assess effectiveness of positive selection in the management of seed borne potato viruses.

\section{Materials and Methods}

\subsection{Study Area and Source of Starting Materials}

Field trials were conducted at the field station in the University of Nairobi Upper Kabete campus in two potato growth seasons; long rains (March to July 2015) and short rains (October, 2015 to February, 2016). The station is located at an altitude of $1940 \mathrm{~m}$, latitude $1^{\circ} 15^{\prime} \mathrm{S}$ and longitude $36^{\circ} 41^{\prime} \mathrm{E}$, in Lower Highland Zone II (LH2) of the Agro-Ecological Zone (AEZs) of Kenya (Jaetzold et al., 2007). The area receives annual rainfall ranging from 1000 to $1006 \mathrm{~mm}$ and average temperatures ranging from $13.7{ }^{\circ} \mathrm{C}$ to $24.3{ }^{\circ} \mathrm{C}$. Nine potato genotypes consisting of 6 International Potato Center (CIP) advanced clones; 398190.200, 300046.22, 393371.157, 393077.159, 392797.22, and 397073.7, and 3 commercial varieties; Asante, Tigoni and Shangi were used. Seed multiplication was done in the field for two seasons, Field Generation One (FG1) and Field Generation Two (FG2) to acclimatize the materials with the climatic conditions of the study area as well as to increase seed volume. Medium size (30-60 mm in diameter) and visually healthy looking tubers were selected from FG2 harvest, and kept inside insect proof diffused light store for two months to break the dormancy and were used as a seed source for this study.

\subsection{Field Experiment}

The experiment was laid out in a randomized complete block design (RCBD) with four blocks each measuring 33 $\mathrm{m}$ by $20 \mathrm{~m}$. Each block was divided into nine plots each measuring $7.5 \mathrm{~m}$ by $6 \mathrm{~m}$ with spacing of $1 \mathrm{~m}$ between each plot. Individual plots were further subdivided into two equal portions for Random Seed Selection (RSS) and Positive Selection (PS) sub-plots. These sub-plots were planted with one hundred sprouted seed potato tubers per genotype from FG2 harvest. After emergence, all agronomic practices were conducted according to good agricultural practices except insect vector control to enhance the high rates of virus transmission in the field.

Ten weeks after planting in FG3, healthy looking plants were selected and pegged in PS sub-plots. The sub-plots were inspected weekly and pegs were removed from plants with newly developed virus disease symptoms. This activity was done until plants began to show senescing (maturity) symptoms. At maturity, pegged plants were harvested separately, and apparently healthy looking tubers of 30-60 $\mathrm{mm}$ in diameter were selected, sprouted in an insect proof diffused light store for two months and used as propagative materials in Positive Selection (PS) 
sub-plots while non-pegged plants provided seed tubers which were used as planting materials in Random Seed Selection (RSS) sub-plots in FG4. The whole cycle was repeated in FG4 growth season as was done in FG3.

\subsection{Detection of Viruses in Seed Potato Tubers}

During the final harvest of FG4, 100 medium (30-60 mm diameter) size and apparently healthy looking tubers were randomly selected from each genotype in both RSS and PS plots, stored in the insect proof diffused light store for two months to break the dormancy, and then tested for presence of viruses. Due to uneven sprouting among the nine genotypes, sub-samples of thirty tubers per genotype were selected from each stock of the sprouted tubers in both RSS and PS samples. One sprout was cored out from each tuber using sterilized knife and planted in a tray of sterilized sand medium in an insect proof greenhouse. Thirty sprouts of each genotype were planted per tray and two different trays were used for each genotype; one from RSS and the other from PS sub-plots. As a result of varied emergence rate among the genotypes, five seedlings at three leaves stages were selected randomly from each genotype from which three leaves were sampled per seedling from top, middle and bottom and tested for presence of the six main potato viruses namely; Potato leaf roll virus (PLRV), Potato virus A (PVA), Potato Virus $M$ (PVM), Potato Virus S (PVS), Potato Virus X (PVX), and Potato Virus $Y$ (PVY) and for their combinations using DAS-ELISA kit (International Potato Center, Lima, Peru), by following Clark and Adam's (1977) protocol. Threshold values were read from ELISA reader at $405 \mathrm{~nm}$ and positive samples determined using the formula $x \geq \bar{x} h \times 2$, where $x=$ Threshold value and $\bar{x} h=$ average value of healthy controls as outlined in the kit.

\subsection{Data Collection and Analysis}

Data on visual potato virus diseas incidences were scored by examining plants showing different virus symptoms like leaf roll and or mosaic symptoms in both experimental plots in FG3 and FG4. This was done on the ninth week after planting.

$$
\text { Virus incidence }(\%)=\frac{\text { Number of symptomatic plants }}{\text { Total number of plants }} \times 100
$$

At harvest, 40 plants per plot were selected randomly and data on the number of tubers per hill and yield in grams per hill was collected for individual genotype. The yields were later converted to tones per hectare (t/ha). Threshold values for the six viruses were recorded for each sample from the ELISA reader and a comparison was made between these values and that of calculated average value of healthy controls. Samples which displayed threshold values equal to or greater than twice the average value of healthy control of each virus were recorded as positive while those with the threshold values less than twice the average value of healthy controls were recorded as negative samples for each virus. Samples which tested positive for different potato viruses were checked for multiple infections.

Data from the field were analyzed using Genstat, 15th version. Mean separation between genotypes and treatments were generally based on the t-test (paired two means) at 5\% probability level for yield and virus incidence. Correlation analyses were conducted to establish the relationship between virus incidence, number of tubers per hill and yield (t/ha) both in FG3 and FG4.

\section{Results}

\subsection{Effect of Positive Selection on Virus Incidence}

Low visual virus incidences were recorded in PS compared to RSS sub-plots in both FG3 (Table 1) and FG4 (Table 2). The virus incidence differed significantly among the genotypes and between RSS and PS sub-plots in both FG3 and FG4. In FG3, Asante had the highest virus incidence of 64\% in PS sub-plots and 69\% in RSS subplots while 398190.200 had the least (2\% in PS sub-plots and 4\% in RSS sub-plots). In FG4, Asante had the highest virus incidence of $67 \%$ in PS sub-plots and 71\% in RSS sub-plots while 397073.7 had the least of 10\% in PS sub-plots and 13\% in RSS sub-plots. Virus incidence increased in both RSS and PS sub-plots in FG4 compared to FG3.

\subsection{Effect of Positive Selection on Number of Tubers per Hill and Yield}

Tuber numbers per hill were significantly higher in PS sub-plots compared to RSS sub-plots in both FG3 (Table 1) and FG4 (Table 2). Shangi had the highest number of tubers per hill in both seasons (13 and 14 tubers per hill in RSS and PS sub-plots of FG3, 10 and 12 tubers per hill in RSS and PS sub-plots of FG4). Genotype 393077.159 had the least number of tubers per hill in FG3; 6 and 8 tubers per hill in RSS and PS sub-plots while 300046.22 had the least number of tubers per hill in FG4, 5 and 7 tubers per hill in RSS and PS sub-plots. However, number of tubers per hill declined in FG4 compared to FG3 in both RSS and PS sub-plots irrespective of the genotypes. 
High potato yields were recorded in PS compared to RSS sub-plots in both FG3 and FG4. The yield in PS sub-plots ranged from 16 to 51 t/ha in FG3 and 7 to 29 t/ha in FG4 compared with 11 to 49 t/ha in FG3 and 5 to $25 \mathrm{t} / \mathrm{ha}$ in FG4 of RSS sub-plots. Average yield differed significantly among genotypes in both RSS and PS sub-plots in both seasons. Genotype 392797.22 had the highest yield in both seasons, 49 and $51 \mathrm{t} /$ ha in RSS and PS sub-plots of FG3, and 25 and 29 t/ha in RSS and PS sub-plots of FG4, respectively. Genotype 393077.159 had the least yield of 25 and $26 \mathrm{t} /$ ha in RSS and PS sub-plots of FG3 while Tigoni had the least yield in RSS and PS sub-plots of FG4. The yield however declined in FG4 compared to FG3 irrespective of the genotypes used in the study.

Table 1. Effects of Positive Selection on virus incidence, number of tubers and yield ( $\mathrm{t} / \mathrm{ha}$ ) in Field Generation Three

\begin{tabular}{|c|c|c|c|c|c|c|c|}
\hline \multirow{2}{*}{ Genotypes } & \multirow{2}{*}{ Treatment $^{1}$} & \multicolumn{2}{|c|}{ Incidence (\%) } & \multicolumn{2}{|c|}{ Number of tubers } & \multicolumn{2}{|c|}{ Yield (t/ha) } \\
\hline & & Mean \pm SD $^{2}$ & p-value ${ }^{3}$ & $\operatorname{Mean} \pm$ SD $^{2}$ & p-value ${ }^{3}$ & Mean \pm SD $^{2}$ & p-value ${ }^{3}$ \\
\hline \multirow[t]{2}{*}{ Asante } & PS & $64.24 \pm 0.81$ & 0.03 & $10.5 \pm 2.26$ & 0.19 & $36.29 \pm 0.93$ & 0.15 \\
\hline & RSS & $69.18 \pm 0.92$ & & $7.80 \pm 1.14$ & & $33.10 \pm 1.46$ & \\
\hline \multirow[t]{2}{*}{393077.159} & PS & $41.65 \pm 1.00$ & 0.01 & $8.03 \pm 0.71$ & 0.10 & $26.88 \pm 0.96$ & 0.03 \\
\hline & RSS & $45.87 \pm 0.53$ & & $6.17 \pm 0.42$ & & $25.62 \pm 0.79$ & \\
\hline \multirow[t]{2}{*}{ Tigoni } & PS & $15.18 \pm 0.51$ & 0.03 & $12.23 \pm 1.01$ & 0.20 & $31.95 \pm 1.58$ & 0.55 \\
\hline & RSS & $18.21 \pm 0.3$ & & $10.83 \pm 0.45$ & & $30.33 \pm 2.77$ & \\
\hline \multirow[t]{2}{*}{393371.157} & PS & $6.18 \pm 0.38$ & 0.01 & $9.40 \pm 1.06$ & 0.04 & $39.05 \pm 1.51$ & 0.12 \\
\hline & RSS & $10.39 \pm 0.42$ & & $7.37 \pm 0.70$ & & $37.21 \pm 1.57$ & \\
\hline \multirow[t]{2}{*}{ Shangi } & PS & $7.21 \pm 1.26$ & 0.08 & $13.51 \pm 2.13$ & 0.06 & $36.07 \pm 2.37$ & 0.27 \\
\hline & RSS & $9.95 \pm 0.83$ & & $12.63 \pm 2.22$ & & $34.54 \pm 1.21$ & \\
\hline \multirow[t]{2}{*}{300046.22} & PS & $4.26 \pm 0.44$ & 0.00 & $9.67 \pm 0.91$ & 0.10 & $31.10 \pm 1.03$ & 0.00 \\
\hline & RSS & $7.29 \pm 0.27$ & & $8.27 \pm 1.11$ & & $29.04 \pm 1.21$ & \\
\hline \multirow[t]{2}{*}{392797.22} & PS & $2.60 \pm 0.36$ & 0.06 & $11.37 \pm 2.68$ & 0.12 & $51.29 \pm 1.73$ & 0.04 \\
\hline & RSS & $4.23 \pm 0.25$ & & $10.27 \pm 2.75$ & & $49.17 \pm 2.27$ & \\
\hline \multirow[t]{2}{*}{397073.7} & PS & $3.79 \pm 0.53$ & 0.02 & $11.9 \pm 2.07$ & 0.05 & $41.10 \pm 1.08$ & 0.08 \\
\hline & RSS & $6.06 \pm 0.27$ & & $10.5 \pm 1.65$ & & $39.13 \pm 1.06$ & \\
\hline \multirow{2}{*}{398190.200} & PS & $2.31 \pm 0.24$ & 0.00 & $10.57 \pm 1.14$ & 0.04 & $49.16 \pm 1.28$ & 0.02 \\
\hline & RSS & $4.17 \pm 0.24$ & & $9.00 \pm 0.53$ & & $46.69 \pm 1.92$ & \\
\hline
\end{tabular}

Note. ${ }^{1}$ PS: Positive Selection, and RSS: Random Seed Selection; ${ }^{2}$ Standard deviation; ${ }^{3}$ Bold values in the column indicate significant difference. 
Table 2. Effects of Positive Selection on virus incidence, number of tubers per hill and yield ( $t /$ ha) in Field Generation Four

\begin{tabular}{|c|c|c|c|c|c|c|c|c|c|}
\hline \multirow{2}{*}{ Genotypes } & \multirow{2}{*}{ Treatments $^{1}$} & \multicolumn{3}{|c|}{ Incidence (\%) } & \multicolumn{3}{|c|}{ Number of tubers } & \multicolumn{2}{|c|}{ Yield (t/ha) } \\
\hline & & \multicolumn{2}{|c|}{ Mean $\pm \mathbf{S D}^{2}$} & \multirow{2}{*}{$\begin{array}{l}\text { p-value } \\
0.00\end{array}$} & \multicolumn{2}{|c|}{$\operatorname{Mean} \pm \mathrm{SD}^{2}$} & \multirow{2}{*}{$\begin{array}{l}p \text {-value } \\
0.03\end{array}$} & Mean $\pm \mathrm{SD}^{2}$ & \multirow{2}{*}{$\begin{array}{l}\text { p-value } \\
0.00\end{array}$} \\
\hline Asante & PS & 67.3 & \pm 0.56 & & 8.20 & \pm 0.70 & & $20.20 \pm 0.20$ & \\
\hline & RSS & 71.67 & \pm 0.57 & & 7.50 & \pm 1.30 & & $17.70 \pm 0.10$ & \\
\hline \multirow[t]{2}{*}{393077.159} & PS & 66.9 & \pm 0.55 & 0.01 & 7.00 & \pm 0.80 & 0.07 & $14.80 \pm 1.00$ & 0.02 \\
\hline & RSS & 70.43 & \pm 0.82 & & 6.00 & \pm 0.50 & & $13.20 \pm 0.20$ & \\
\hline \multirow[t]{2}{*}{ Tigoni } & PS & 45.84 & \pm 0.65 & 0.01 & 6.50 & \pm 0.20 & 0.03 & $12.90 \pm 1.50$ & 0.11 \\
\hline & RSS & 49.67 & \pm 0.7 & & 5.80 & \pm 0.06 & & $11.80 \pm 0.10$ & \\
\hline \multirow[t]{2}{*}{393371.157} & PS & 19.56 & \pm 0.45 & 0.00 & 8.10 & \pm 1.10 & 0.07 & $23.10 \pm 1.30$ & 0.15 \\
\hline & RSS & 22.87 & \pm 0.36 & & 7.00 & \pm 0.30 & & $22.20 \pm 0.20$ & \\
\hline \multirow[t]{2}{*}{ Shangi } & PS & 20.87 & \pm 0.78 & 0.03 & 12.20 & \pm 0.50 & 0.00 & $22.20 \pm 1.30$ & 0.00 \\
\hline & RSS & 24.37 & \pm 0.42 & & 9.80 & \pm 1.10 & & $14.40 \pm 0.20$ & \\
\hline \multirow[t]{2}{*}{300046.22} & PS & 26.78 & \pm 0.36 & 0.02 & 6.70 & \pm 0.50 & 0.01 & $20.10 \pm 1.50$ & 0.00 \\
\hline & RSS & 29.74 & \pm 0.64 & & 5.10 & \pm 0.40 & & $12.90 \pm 0.30$ & \\
\hline \multirow[t]{2}{*}{392797.22} & PS & 16.39 & \pm 0.63 & 0.03 & 9.00 & \pm 1.20 & 0.10 & $29.20 \pm 1.40$ & 0.01 \\
\hline & RSS & 19.2 & \pm 0.67 & & 7.50 & \pm 0.70 & & $25.00 \pm 0.10$ & \\
\hline \multirow[t]{2}{*}{397073.7} & PS & 10.28 & \pm 0.7 & 0.03 & 8.40 & \pm 1.00 & 0.03 & $21.80 \pm 0.40$ & 0.00 \\
\hline & RSS & 13.34 & \pm 0.27 & & 6.90 & \pm 0.30 & & $18.70 \pm 0.10$ & \\
\hline \multirow[t]{2}{*}{398190.200} & PS & 25.28 & \pm 0.49 & 0.00 & 8.00 & \pm 0.70 & 0.06 & $20.80 \pm 0.50$ & 0.02 \\
\hline & RSS & 28.44 & \pm 0.41 & & 6.60 & \pm 0.60 & & $19.80 \pm 0.10$ & \\
\hline
\end{tabular}

Note. ${ }^{1}$ PS: Positive Selection, and RSS: Random Seed Selection; ${ }^{2}$ SD: Standard deviation; ${ }^{3}$ Bold values in the column indicate significant difference.

\subsection{Correlation among Virus Incidence, Number of Tubers per Hill and Yield in RSS and PS Plots}

Virus incidence negatively correlated to the number of tubers per hill in all genotypes except for Asante and 393077.159 in RSS and PS sub-plots in both FG3 (Table 3) and FG4 (Table 4). However, the correlation coefficients were not significant except for Tigoni in FG3. Virus incidence demonstrated insignificant negative correlation to yield in both RSS and PS sub-plots in FG3 and FG4. Number of tubers per hill demonstrated strong positive correlation to yield in both RSS and PS sub-plots in FG3 and FG4. The correlation coefficients were not significant except for RSS of genotype 300046.22 and PS of genotype 392797.22 in FG3.

Table 3. Correlation coefficients among virus incidence, number of tubers per hill and total yield (t/ha) of different potato genotypes in Field Generation Three (FG3)

\begin{tabular}{|c|c|c|c|c|c|c|c|}
\hline Genotypes & Treatments $^{1}$ & $V V I^{2}-T B N^{3}$ & P-value $^{4}$ & $V_{V I}{ }^{2}$-Yield & P-value $^{4}$ & TBN $^{4}$-Yield & P-value ${ }^{4}$ \\
\hline \multirow[t]{2}{*}{300046.22} & RSS & -0.94 & 0.22 & -0.95 & 0.19 & 1.00 & 0.03 \\
\hline & PS & -0.65 & 0.55 & -1.00 & 0.06 & 0.72 & 0.49 \\
\hline \multirow[t]{2}{*}{ Tigoni } & RSS & -1.00 & 0.04 & -0.66 & 0.54 & 0.71 & 0.50 \\
\hline & PS & -1.00 & 0.05 & -0.89 & 0.3 & 0.92 & 0.25 \\
\hline \multirow[t]{2}{*}{ Asante } & RSS & 0.21 & 0.87 & -0.87 & 0.32 & 0.66 & 0.54 \\
\hline & PS & 0.20 & 0.87 & -0.57 & 0.61 & 0.69 & 0.51 \\
\hline \multirow[t]{2}{*}{392797.22} & RSS & -0.30 & 0.80 & -0.68 & 0.53 & 0.91 & 0.28 \\
\hline & PS & -0.49 & 0.67 & -0.49 & 0.67 & 1.00 & $<0.001$ \\
\hline \multirow[t]{2}{*}{393077.159} & RSS & 0.13 & 0.92 & -0.97 & 0.17 & 0.38 & 0.75 \\
\hline & PS & 0.99 & 0.09 & -0.72 & 0.49 & 0.61 & 0.58 \\
\hline \multirow[t]{2}{*}{393371.157} & RSS & -0.96 & 0.18 & -0.64 & 0.56 & 0.39 & 0.74 \\
\hline & PS & -0.25 & 0.84 & -0.44 & 0.71 & 0.98 & 0.13 \\
\hline \multirow[t]{2}{*}{397073.7} & RSS & -0.87 & 0.33 & -0.83 & 0.37 & 0.45 & 0.70 \\
\hline & PS & -0.79 & 0.42 & -0.55 & 0.63 & 0.95 & 0.21 \\
\hline \multirow[t]{2}{*}{398190.200} & RSS & -0.98 & 0.12 & -0.95 & 0.21 & 0.87 & 0.33 \\
\hline & PS & -0.90 & 0.28 & -0.99 & 0.11 & 0.82 & 0.39 \\
\hline \multirow[t]{2}{*}{ Shangi } & RSS & -0.06 & 0.96 & -0.38 & 0.76 & 0.95 & 0.21 \\
\hline & PS & -0.06 & 0.96 & -0.38 & 0.76 & 0.95 & 0.21 \\
\hline
\end{tabular}

Note ${ }^{1}$ RSS: Random Seed Selection, and PS: Positive Selection; ${ }^{2}$ VVI: Visual Virus Incidence; ${ }^{3}$ TBN: Tubers number; ${ }^{4}$ Bold values in the column indicate significant difference. 
Table 4. Correlation coefficients among virus incidence, number of tubers per hill and total yield (t/ha) of different potato genotypes in Field Generation Four (FG4)

\begin{tabular}{|c|c|c|c|c|c|c|c|}
\hline Genotypes & Treatments ${ }^{1}$ & $V V I^{2}-T_{B N}^{3}$ & P-value ${ }^{4}$ & VVI' ${ }^{2}$-Yield & P-value ${ }^{4}$ & TBN $^{4}$-Yield & P-value ${ }^{4}$ \\
\hline \multirow[t]{2}{*}{300046.22} & RSS & -0.49 & 0.51 & -0.08 & 0.92 & 0.23 & 0.77 \\
\hline & PS & -0.08 & 0.92 & -0.88 & 0.12 & 0.55 & 0.45 \\
\hline \multirow[t]{2}{*}{ Tigoni } & RSS & -0.40 & 0.60 & -0.36 & 0.64 & 0.91 & 0.09 \\
\hline & PS & -0.80 & 0.20 & -0.42 & 0.58 & 0.12 & 0.88 \\
\hline \multirow[t]{2}{*}{ Asante } & RSS & 0.29 & 0.71 & -0.81 & 0.19 & 0.40 & 0.60 \\
\hline & PS & 0.40 & 0.6 & -0.75 & 0.25 & 0.13 & 0.87 \\
\hline \multirow[t]{2}{*}{392797.22} & RSS & -0.18 & 0.82 & -0.3 & 0.70 & 0.88 & 0.12 \\
\hline & PS & -0.54 & 0.46 & -0.47 & 0.53 & 0.10 & 0.90 \\
\hline \multirow[t]{2}{*}{393077.159} & RSS & 0.62 & 0.38 & -0.01 & 0.99 & 0.53 & 0.47 \\
\hline & PS & 0.55 & 0.45 & -0.16 & 0.84 & 0.73 & 0.27 \\
\hline \multirow[t]{2}{*}{393371.157} & RSS & -0.79 & 0.21 & -0.97 & 0.03 & 0.64 & 0.36 \\
\hline & PS & -0.45 & 0.55 & -0.08 & 0.92 & 0.83 & 0.17 \\
\hline \multirow[t]{2}{*}{397073.7} & RSS & -0.59 & 0.41 & -0.04 & 0.96 & 0.63 & 0.37 \\
\hline & PS & -0.77 & 0.23 & -0.62 & 0.38 & 0.01 & 0.99 \\
\hline \multirow[t]{2}{*}{398190.200} & RSS & -0.39 & 0.61 & -0.43 & 0.57 & 0.53 & 0.47 \\
\hline & PS & -0.56 & 0.44 & -0.99 & 0.01 & 0.67 & 0.33 \\
\hline \multirow[t]{2}{*}{ Shangi } & RSS & -0.68 & 0.32 & -0.92 & 0.08 & 0.86 & 0.14 \\
\hline & PS & -0.06 & 0.94 & -0.12 & 0.88 & 0.50 & 0.50 \\
\hline
\end{tabular}

Note. ${ }^{1}$ RSS: Random Seed Selection, and PS: Positive Selection; ${ }^{2}$ VVI: Visual Virus Incidence; ${ }^{3}$ TBN: Tubers number; ${ }^{4}$ Bold values in the column indicate significant difference.

\subsection{Latent Virus Infection in Field Generation Four (FG4)}

Among the tested tubers for different viruses from PS sub-plots, PVS (47\%) were the most predominant while PVY, PLRV, PVA, PVM and PVX were absent in the tested tubers. Eight genotypes tested positive for PVS. Results of tested tubers from RSS sub-plots also revealed PVS (78\%) as the most dominant virus followed by PVY (20\%), PLRV (16\%) and PVM (9\%). Potato Virus A (PVA) and PVX were absent in the tested tubers. All the nine potato genotypes tested positive for PVS; five genotypes for PVY, four genotypes for PLRV while only two genotypes tested positive for PVM. One genotype showed mixed infections to PVS + PVY, one genotype to PVM + PVS; one genotype to PLRV + PVM + PVS + PVY and three genotypes to PLRV + PVS + PVY in the tested tubers from RSS (Table 5). Average visual virus incidences scored in the field were high in both RSS and PS sub-plots compared to virus incidences from ELISA test results on tubers.

Table 5. Percent incidences of potato viruses observed at 9 weeks after planting in the field and in seed tubers harvested in Field Generation Four from Random Seed Selection and Positive Selection plots

\begin{tabular}{|c|c|c|c|c|c|c|c|c|c|c|c|c|c|c|}
\hline \multirow{3}{*}{ Genotype } & \multirow{2}{*}{\multicolumn{2}{|c|}{$\begin{array}{l}\text { Virus incidence based } \\
\text { on visual observation }^{1}\end{array}$}} & \multicolumn{12}{|c|}{ Virus incidences (\%) based on DAS Elisa test ${ }^{2,3}$} \\
\hline & & & \multicolumn{2}{|c|}{ PLRV } & \multicolumn{2}{|c|}{ PVA } & \multicolumn{2}{|c|}{ PVM } & \multicolumn{2}{|c|}{ PVS } & \multicolumn{2}{|c|}{ PVX } & \multicolumn{2}{|c|}{ PVY } \\
\hline & RSS & PS & RSS & PS & RSS & PS & RSS & PS & RSS & PS & RSS & PS & RSS & PS \\
\hline Shangi & 24.37 & 20.87 & 0 & 0 & 0 & 0 & 0 & 0 & 60 & 0 & 0 & 0 & 20 & 0 \\
\hline Asante & 71.67 & 67.30 & 0 & 0 & 0 & 0 & 0 & 0 & 40 & 20 & 0 & 0 & 0 & 0 \\
\hline Tigoni & 49.67 & 45.84 & 20 & 0 & 0 & 0 & 40 & 0 & 100 & 80 & 0 & 0 & 20 & 0 \\
\hline 397073.7 & 13.34 & 10.28 & 0 & 0 & 0 & 0 & 40 & 0 & 60 & 40 & 0 & 0 & 0 & 0 \\
\hline 300046.22 & 29.74 & 26.78 & 20 & 0 & 0 & 0 & 0 & 0 & 100 & 80 & 0 & 0 & 60 & 0 \\
\hline 392797.22 & 19.20 & 16.39 & 80 & 0 & 0 & 0 & 0 & 0 & 40 & 20 & 0 & 0 & 20 & 0 \\
\hline 393371.157 & 22.87 & 19.56 & 0 & 0 & 0 & 0 & 0 & 0 & 100 & 60 & 0 & 0 & 0 & 0 \\
\hline 393077.159 & 70.43 & 66.90 & 20 & 0 & 0 & 0 & 0 & 0 & 100 & 60 & 0 & 0 & 60 & 0 \\
\hline 398190.200 & 28.44 & 25.28 & 0 & 0 & 0 & 0 & 0 & 0 & 100 & 60 & 0 & 0 & 0 & 0 \\
\hline
\end{tabular}

Note. ${ }^{1}$ RSS: Random Seed Selection, PS: Positive Selection; ${ }^{2}$ PLRV: Potato leaf roll virus, PVA: Potato virus A, PVY: Potato virus Y, PVM: Potato virus M, PVS: Potato virus S, PVX: Potato virus $X ;{ }^{3}$ Some of the genotypes had mixed infections by two or three viruses, 0 in virus columns means no detection of virus. 


\section{Discussion}

From this study, it was evident that Positive Selection reduced visual virus incidence in the experimental field in both seasons but this is difficult to prove since some potato viruses always have latent infections and cannot be easily identified using visual symptoms (Njukeng et al., 2013). The lower virus incidences in PS plots might be due to the low concentrations or absence of virus inoculum in asymptomatic plants selected as seed source in PS plots (Gildemacher et al., 2011; Schulte-Geldermann et al., 2012). Genotypes used in the study responded differently to PS with regards to virus incidence in both seasons suggesting that there is genotype variation to PS which could have been attributed to their genetic traits (Solomon-Blackburn \& Barker, 2001). Increased virus incidence in FG4 compared to FG3 might be due to the absence of insect vector (aphid) control strategies in the experimental field (Kabira et al., 2006) or due to abiotic factors like water stress (Batool et al., 2011). Field Generation Four (FG4) was a short rain season with low rainfall amounts which could have led to draught stress, and high insect vector populations predisposing the crop to high virus infections and hence might have increased the virus incidence.

Higher number of tubers per hill and yield (t/ha) in PS sub-plots might have been attributed to low virus incidences recorded in PS sub-plots. However, percent increase in number of tubers per hill and yield ( $t / h a)$ through use of positive selection varied among genotypes signifying that Positive Selection is genotype/variety dependent (Schulte-Geldermann et al., 2012). Genotype 392797.22, 398190.200, 397073.7, 393371.157, Shangi and Asante recorded high number of tubers per hill and yield (t/ha) in PS sub-plots in both FG3 and FG4 signifying good response of these genotypes to Positive Selection technique. Schulte-Geldermann et al. (2012) also reported the increase of $30 \%$ yield via Positive Selection as compared to farmer selection, while Gildemacher et al. (2011) reported a yield increase of $28 \%$ to $54 \%$, which is similar to our findings. This study also revealed a decline in number of tubers per hill and yield in both RSS and PS sub-plots of FG4 in comparison to FG3. The decline in number of tubers per hill and yields observed in FG4 can be attributed to increase in virus incidence recorded in FG4 (Rahman et al., 2010; Ali et al., 2013; Islam et al., 2014). Salazar (1996) reported that yield losses in potato fields increased with increasing symptom appearance on the foliage which was also observed in this study. ELISA test results revealed that PVS was infecting all the genotypes collected from RSS sub-plots and 8 genotypes from PS subplots in FG4. Potato Virus $S$ can reduce yield up to 10-32\% (Piche et al., 2004), and this can also explain lower yields in FG4. Lower yield might also have occurred due to low soil moisture availability during and after tuber initiation in FG4 (short rain season). Water stress during vegetative growth might have reduced leaf area and plant height resulting in low photosynthetic products stored in the tubers and tuber expansion, hence low yields (Alva, 2008).

Analysis of relationship between virus incidence, number of tubers per hill and yield in both FG3 and FG4 in RSS and PS sub-plots revealed that there was a reduction in number of tubers per hill and yield ( $/$ ha) with the increase in virus incidence. This reduction in yield parameters may have resulted from declining physiological disease resistance mechanisms in potato plants accruing from increased infections by potato viruses in the experimental fields (Salazar, 1996). However, some genotypes like Asante and 393077.159 displayed positive correlation between virus incidence and tuber number per hill. This might be an indication that some potato varieties respond to increased virus infections by producing many medium and small sized tubers (Njukeng et al., 2013; Bornventure et al., 2017). The analysis also revealed that most of the correlation coefficients were not significant, and this might be an indication that reduction in number of tubers per hill and yield might also have occurred due to other abiotic and biotic factors such as water stress during crop growth and insect pest infestation (Pereira \& Nova, 2008; Batool et al., 2011). Rahman et al. (2010), and Islam et al. (2014) also reported a negative correlation between number of tubers per hill and yield in their study. The study also revealed that yield $(\mathrm{t} / \mathrm{ha})$ increases with increasing tuber number per hill. Increasing tuber number results into increased volume and weight, hence yield (t/ha) (Tuncturk et al., 2005).

ELISA test revealed that Potato Virus $\mathrm{S}$ was the most predominant and was detected to infect all the nine genotypes followed by PVY, PLRV and PVM, respectively. High incidences of PVS may have occurred due to its ability to pass through tissue culture process which is usually adopted in production of certified seeds (Were et al., 2013) or because PVS is mainly transmitted mechanically, it could have spread by farmers during farm operations (Gul et al., 2013). Low incidences of PLVR, PVM and PVY as well as zero detection of PVA and PVX in RSS tuber samples may be attributed to restricted spread of these viruses due to the absence of insect vectors and alternate hosts in the experimental site (Djilani-Khouadja et al., 2010). Were et al. (2013) also reported that PVS as the most detected virus followed by PVY, PVX, and PLRV in samples collected from potato growing districts in Kenya. Yardimci et al. (2015) also reported that PVS and PVY as the most prevalent potato viruses in potato growing areas in Turkey when ELISA tests were conducted on tubers. In addition, 
Yardimci et al. (2015) reported PVY+PVS (9.17\%) as one of the most common multiple infections in potato (tubers) as revealed in this study. Potato Virus $S$ was detected from PS sub-plots, however the tuber virus incidences were low compared to those detected in RSS sub-plots. This might be because of low viral loads in the seed tubers collected from apparently healthy looking mother plants were planted in PS sub-plots (Gildemacher et al., 2011). Predominant presence of PVS in this study indicates that it is difficult to select seed potato tubers free from these viruses via Positive Selection technique. The study also revealed that efficiency of positive selection technique is genotypes/variety and virus dependent (Schulte-Geldermann et al., 2012). Furthermore, seed potato tubers free from PVY, PLRV, PVM, PVA and PVX can be selected with a high degree of certainty using positive selection as demonstrated in this study and by Njukeng et al. (2013).

Analysis of virus incidences scored in the field and those detected in seed tubers revealed that average visual virus incidences scored in the field were high in both RSS and PS sub-plots compared to virus incidences from ELISA test on tubers. This could be because some potato viruses like PLRV and PVY are easily expressed on leaves while PVS and PVM are usually asymptomatic in most field conditions (Njukeng et al., 2013). These viruses might also have been present in the tested tubers but in low concentrations which could not be detected by the kit (El-Araby et al., 2009). PLRV was also detected in some resistant genotypes like 392797.22 and 393077.159 from RSS sub-plots while PVY was detected 392797.22 and 300046.22 from RSS sub-plots. This may be an indication that these genotypes lose their resistance after multiples seasons of exposure to natural virus pressure in the field.

Positive selection was effective in the management of potato viruses in the field. In addition, there was a reduction in virus incidences of PLRV, PVS, PVY and PVM in plots planted with positively selected seed potato tubers compared to the conventional farmers' practice of random seed selection in all the genotypes. Yield also increased with the use of positive selection but percentage increase was genotype dependent. Farmers should be sensitized on the importance of positive selection in management of seed borne potato viruses. Genotypes 392797.22, 398190.200, 397073.7, 393371.157, Shangi and Asante that showed good response to Positive Selection should be promoted for adoption by farmers to reduce yield loss from potato viruses. Positive selection study should be carried out in multiple seasons to determine the maximum generation above which its effectiveness starts to decline. More advanced virus detection methods (molecular methods) should be incorporated into the study since DAS-ELISA is not sensitive enough to detect the lower concentration of viruses (concentrations with titer values lower than twice the average value of healthy controls of the tested virus).

\section{Acknowledgements}

The authors acknowledge the Federal Ministry for Economic Cooperation and Development (BMZ) of Germany for funding the research. Additional funding was provided by, the CGIAR Research Program on Roots, Tubers and Bananas (RTB) and supported by CGIAR Fund Donors.

\section{References}

Ali, S., Kadian, M. S., Ortiz, O., Singh, B. P., Chandla, V. K., \& Akhtar, M. (2013). Degeneration of potato seed in Meghalaya and Nagaland states in North-Eastern Hills of India. Potato Journal, 40(2), 122-127.

Alva, A. K. (2008). Water management and water uptake efficiency by potatoes: A review. Archives of Agronomy and Soil Science, 54(1), 53-68. https://doi.org/10.1080/03650340701615822

Batool, A., Khan, M. A., Farooq, J., Mughal, S. M., \& Iftikhar, Y. (2011). ELISA-based Screening of Potato germplasm against Potato Leaf Roll Virus. Journal of Agricultural Research, 49, 57-63.

Bornventure, M. I., Muthomi, J. W., Narla, R. D., Nyongesa, M., \& Olubayo, F. M. (2017). Effect of seed potato tuber storage methods on occurrence of potato diseases. International Journal of Research in Agricultural Sciences, 4(4), 2348-3997.

Clark, M. F., \& Adams, A. N. (1977). Characteristics of the microplate method of enzyme-linked immunosorbent assay for the detection of plant viruses. Journal of General Virology, 34(3), 475. https://doi.org/10.1099/0022-1317-34-3-475

Gul, Z., Khan, A. A., Khan, A. U., \& Khan, Z. U. (2013). Incidence of potato viruses in different districts of Khyber Pakhtunkhawa, Pakistan. International Journal of Phytopathology, 2(1), 32-36.

Islam, A. K. M. S., Akanda, A. M., Wazed, M. A., Chewdhery, M. R. A., \& Rahman, M. J. (2014). Performance of fifth generation seed potato against Potato virus Y (PVY). Schorlarly Journal of Agricultural Science, $4(2), 74-81$. 
Jaetzold, R., Ira, F., Schmidt, H., Hornet, B., \& Shisanya, C. (2007). Farm Management Handbook of Kenya-Natural conditins and farm management information. Part B: Central Kenya (2nd edition Vol. II). Ministry of Agriculture/GTZ, Nairobi Kenya.

Janssens, S. M. R. M., Wiersema, S. G., \& Goos, H. T. (2013). The value chain for seed and ware potatoes in Kenya: Opportunities for development. Retrieved November 5, 2017, from http://www.akkerwijzer.nl/ upload/files/1381309822Aardappelteelt_in_Kenia.pdf

Kabira, J. N., Wakahiu, M., Wagoire, W., Gildemacher, P., \& Lemaga, B. (2006). Guidelines for production of healthy seed potatoes in East and Central Africa (pp. 1-26). Kenya Agricultural Research Institute, Nairobi, Kenya.

Kyamanywa, S., Kashaija, I. N., Getu, E., Amata, R., Senkesha, N., \& Kullaya, A. (2011). Enhancing food security through improved seed systems of appropriate varieties of cassava, potato and sweetpotato resilient to climate change in Eastern Africa. ILRI, Kenya. Retrieved November 16, 2017, from https://dspacetest.cgiar.org/bitstream/handle/10568/10817/Project2_Cassava.pdf?sequence=6

NCPK (National Potato Council of Kenya). (2013). A Guide to Potato Production and Postharvest Management in Kenya. Retrieved from https://npck.org/Books/potato\%20production\%20manual.pdf

Njukeng, A., Chewachong, M. G., Chofong, G., Demo, P., Sakwe, P., \& Njualem, K. D. (2013). Determination of scanned virus-free potato planting materials by positive selection and screening of tubers from seed stores in the western highlands of Cameroon. International Journal of Biological and Chemical Sciences, 7(2), 707-716. https://doi.org/10.4314/ijbcs.v7i2.25

Pereira, A., \& Nova, N. V. (2008). Potato maximum yield as affected by crop parameters and climatic factors in Brazil. Journal of Horticultural Sciences, 43(5), 1611-1614.

Piche, L. M., Singh, R. P., Nie, X., \& Gudmestad, N. C. (2004). Diversity among Potato Virus Y isolates obtained from potatoes grown in the United States. Journal of Phytopathology, 94, 1368-1375. https://doi.org/10.1094/ PHYTO.2004.94.12.1368

Rahman, M. S., Akanda, A. M., Mian, I. H., Bhuian, M. K. A., \& Karim, M. R. (2010). Growth and yield performance of different generations of seed potato as affected by PVYand PLRV. Bangladesh Journal of Agricultural Research, 35(1), 37-50. https://doi.org/10.3329/bjar.v35i1.5865

Salazar, L. F. (1996). Potato viruses and their control. International Potato Center ISBN 9290601841. pp. 1-241.

Schulte-Geldermann, E. (2013). Tackling Low Potato Yields in Eastern Africa: An Overview of Constraints and Potential Strategies. Seed Potato Tuber Production and Dissemination. In G. Woldegiorgis, S. Schulz, \& B. Berihun (Eds.). Seed potato tuber production and dissemination, experiences, challenges and prospects: Proceedings of National Workshop on Seed Potato Tuber Production and Dissemination, Bahir Dar Ethiopia (pp. 72-80). Ethiopian Institute of Agricultural Research; Amhara Regional Agricultural Research Institute; International Potato Center.

Schulte-Geldermann, E., Gildemacher, P. R., \& Struik, P. C. (2012). Improving seed health and seed performance by positive selection in three Kenyan potato varieties. American Journal of Potato Research, 89(6), 429-437. https://doi.org/10.1007/s12230-012-9264-1

Solomon-Blackburn, R. M., \& Barker, H. (2001). Breeding virus resistant potatoes (Solanum tuberosum): A review of traditional and molecular approaches. Journal of Heredity, 86(1), 17-35. https://doi.org/10.1046/ j.1365-2540.2001.00799.x

Thomas-Sharma, S., Abdurahman, A., Ali, S., Andrade-Piedra, J. L., Bao, S., Charkowski, A. O., ... Forbes, G. A. (2016). Seed degeneration in potato: the need for an integrated seed health strategy to mitigate the problem in developing countries. Plant Pathology, 65, 3-16. https://doi.org/10.1111/ppa.12439

Tshisola, S. N. (2014). Improved potato (Solanum tuberosum) seed production through aeroponics system. (Doctoral dissertation, Stellenbosch: Stellenbosch University).

Tuncturk, M., \& Ciftci, V. (2005). Selection criteria for potato (Solanum tuberosum L.) breeding. Asian Journal of Plant Sciences, 4(1), 27-30. https://doi.org/10.3923/ajps.2005.27.30

Wang'ombe, J. G., \& van Dijk, M. P. (2013). Low potato yields in Kenya: Do conventional input innovations account for the yields disparity? Journal of Agriculture and Food Security, 2, 14. https://doi.org/10.1186/ 2048-7010-2-14 
Were, H. K., Kabira, J. N., Kinyua, Z. M., Olubayo, F. M., Karinga, J. K., Aura, J., \& Torrance, L. (2013). Occurrence and distribution of potato pests and diseases in Kenya. Potato Research Journal, 56(4), $325-342$. https://doi.org/10.1007/s11540-013-9246-9

Yardimci, N., Çulal Kılıç, H., \& Demir, Y. (2015). Detection of PVY, PVX, PVS, PVA, and PLRV on different potato varieties in Turkey using DAS-ELISA. Journal of Agricultural Science and Technology, 17(3), 757-764.

\section{Copyrights}

Copyright for this article is retained by the author(s), with first publication rights granted to the journal.

This is an open-access article distributed under the terms and conditions of the Creative Commons Attribution license (http://creativecommons.org/licenses/by/4.0/). 